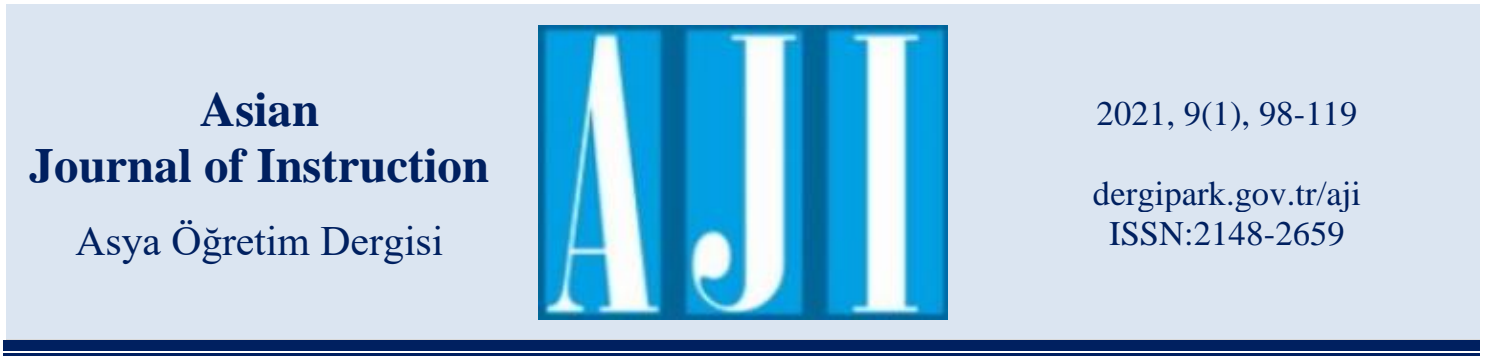

Kabul Tarihi: 24/06/2021

Yayınlanma Tarihi: 25/06/2021

\title{
Zorunlu Göçe Maruz Kalan Çocukların Psikolojik İyilik Hallerinin Incelenmesi*
}

\author{
Ali Can Başay ${ }^{1}$, Abide Güngör Aytar ${ }^{2}$
}

Başay, A. C., \& Güngör Aytar, A. (2021). Zorunlu göçe maruz kalan çocukların psikolojik iyilik hallerinin incelenmesi. Asya Ö̆gretim Dergisi, 9(1), 98-119. https://doi.org/10.47215/aji.852325

$\ddot{O} z$

Bu araştırma ile zorunlu göçe maruz kalan çocukların psikolojik iyilik hallerinin yaşam doyumu kavramı bağlamında incelenmesi amaçlanmıştır. Araştırmanın çalışma grubu, zorunlu göçe maruz kalan ve Ankara'da 2017-2018 eğitim öğretim yılında ilkokul 2. kademede öğrenim gören çocuklardan oluşmaktadır. Çalışma karma yöntem araştırma modellerinden açımlayıcı sıralı karma yöntem deseninde gerçekleştirilmiştir. Çalışmanın nicel boyutunda, Çivitçi (2007) tarafından Türkçe'ye uyarlanan Çok Boyutlu Öğrenci Yaşam Doyumu Ölçeği (ÇÖYDÖ) ve araştırmac1 tarafından hazırlanan kişisel bilgi formu 96 çocuğa uygulanmıştır. Elde edilen veriler analiz edilmiş ve ÇÖYDÖ'den alınan puanlar için en düşük ve en yüksek puan grupları belirlenmiştir. Araştırmanın nitel boyutunda ise dört düşük (2 kız, 2 erkek) ve dört yüksek (2 kız, 2 erkek) puan grubundaki toplam sekiz çocuk ile görüşme yapılmıştır. Araştırmanın sonuçlarına göre, ÇÖYDÖ’den alınan puanların cinsiyet, yaş ve öğrenim görülen sınıf değişkenleri açısından istatistiki olarak anlamlı bir farklılık göstermediği, ÇÖYDÖ'den düşük ve yüksek puan alan çocukların yaşam doyumları arasında anlamlı farklılıkların olduğu, bu farklılıkların, süreğen hastalığa sahip olma, içinde yaşadıkları mahallenin şartları, arkadaş ilişkileri, gelişimsel risk yaşama ve olumsuz yaşam değerlendirmeleri alt boyutlarında ortaya çıktığı sonucuna ulaşılmıştır.

Anahtar Kelimeler: Çocuk, göç, psikolojik iyilik hali, yaşam doyumu

\section{Examining the Psychological Well-being of Children Exposed to Forced Migration}

\begin{abstract}
The aim of this study is to investigate the psychological well-being of children exposed to forced migration in the context of life satisfaction. The sample of the study consisted of children subjected to forced immigration and who were in the second grade of primary school in 2017-2018 academic year in Ankara. The study was carried out in exploratory mixed method design, one of the mixed method research models. In the quantitative dimension of the study, the information form prepared by the researcher and the Multidimensional Student Satisfaction Scale (MSSLTR) adapted to Turkish by Çivitçi (2007) were applied to 96 students. The obtained data were analyzed and the minimum and high score limits of the scores obtained from the (MSSL-TR) were determined. In the qualitative stage of the study, eight children with low four ( 2 girls, 2 boys) and high four ( 2 girls, 2 boys) scores were interviewed.

* Bu çalışma 11.07.2013 tarihli ve 28704 sayılı Göç Uzmanlığı Yönetmeliği kapsamında uzmanlık tezi olarak kabul edilmiştir ve 2018 Uluslararası Sınıf Öğretmenliği Sempozyumu’nda sözlü bildiri olarak sunulmuştur.

${ }^{1}$ Göç Uzmanı, Göç İdaresi Genel Müdürlüğü, https://orcid.org/0000-0001-6027-954X, a.can.basay@gmail.com.tr

${ }^{2}$ Prof. Dr., Gazi Ünivesitesi, https://orcid.org/0000-0002-0327-3317, abidegüngor@gmail.com.tr
\end{abstract}


According to the results of the research, it was understood that the scores obtained from the MSSL-TR did not show a statistically significant difference in terms of gender, age and grade variables. It was understood that there are significant differences in life satisfaction of children within the low and high score of MSSL-TR, the differences occur in sub-dimensions of having chronic illness, the conditions of the neighborhood they live in, friend relations, developmental risk living and negative life evaluations.

Keywords: Child, migration, psychological well-being, life satisfaction

\section{Giriş}

Göç, insanların bir yerden bir yere hareket ederek kendilerine yeni yaşam alanları oluşturdukları, insanlık tarihi kadar eski bir olgudur. Göç kavramı ile öncelikle belli bir nüfusun bir bölgeden başka bir yere olan hareketi akla gelmekle birlikte, göç coğrafi bir yer değiştirmeden çok daha kapsamlı ve köklü bir anlam taşımaktadır (Sağlam, 2006). Göçü, daha iyi bir yaşam şansı arayışıyla kişinin başka bir yere göç etmesi, doğduğu yerle köklerini koparması ve yeni bir ülkede çabucak asimile olması gibi basit bireysel bir eylem olarak değerlendirmek oldukça güçtür. Göç ve yerleşme, göçmenin geriye kalan hayatını kuşatan ve sonraki kuşakları da etkileyen uzun soluklu bir süreçtir (Castles \& Miller, 2008).

Yeni firsatlara ve imkanlara erişmek, yaşam standartlarının ve refah seviyesinin artırılmasının hedeflendiği göçler her zaman istenilen şekilde sonuçlanmamaktadır. Göç biçimi, etkileri ve uzun süreli sonuçları itibariyle, kötü hayat koşullarından kurtulma gibi firsatları ve beklentilerin karşılanamaması gibi dezavantajları içerisinde barındırmaktadır. Gönüllü yapılan göçler gelişimi ve uyumu kolaylaştırırken, zorunlu göçler finansal, fiziksel ve eğitimsel koşulların çoğunlukla kötüleşmesi, toplumsal destek sisteminin kaybedilmesi, çocuğun eğitimi, tıbbi bakım ve sağlıksız beslenme koşulları gibi çeşitli risk unsurlarını içinde barındırır (Beter, 2006; Buz, 2003). Bu durum yaşamın erken dönemlerindeki çocuklar için gelişimsel açıdan daha yıkıcı sonuçlara neden olabilmektedir. Çocukların istendik gelişimsel kazanımlar edinmesi başta gelişim, öğretme ve psikoloji alanında çalışanlar olmak üzere toplumun tüm fertlerinin temel hedeflerindendir. Zorlayıcı ve travmatik yaşantılardan olan zorunlu göç özellikle çocuklarda içsel gerilimin bir yansıması olarak tikler, soyutlanma nedeniyle yalnızlık ve içe kapanma, çaresizlik hissi ve umutsuzluk gibi çeşitli uyum ve davranış problemleri ile sonuçlanabilmektedir (Akduman, 2014; Battal \& Özmenler, 1997). Çocuğun yerinden edilme nedeniyle yaşadığı uyum ve davranış problemleri onun iyilik halini olumsuz etkilemekte ve gelişimsel hedeflere ulaşmasını engelleyebilmektedir.

İyilik hali, genel olarak bireyin kendisini çeşitli göstergeler ve referans grupları açısından ele alarak değerlendirmesi ve yaşam doyumu skalasındaki yerini belirlemesidir (Akın \& Akın, 2015; Hefferon \& Boniwell, 2014). Bireyin kendisini yaşam doyumu skalasında üst sıralara yerleştirmesi mutluluk, ruh sağlığı ve gelişimsel açısından olumlu sonuçları meydana getirmektedir. Ayrıca iyilik halinin korunması ve sürdürülebilirliği bireylerin sağlıklı gelişimi ve uyumu açısından da önemli bir unsurdur. Çocukların iyilik hali değerlendirmelerinde ise hem çocukların kendi yaşam doyumları açısından görüşlerinin alınması hem de yaşam koşullarına ilişkin çeşitli göstergelerin incelenmesi gerekmektedir. Bununla birlikte iyilik hali çerçevesinin belirlenmesinde evrensel normlardan çok farklı kültürlere göre çeşitlilik söz konusudur (Casas, 1998).

Zorunlu göç sonrası çocukların maruz kalabileceği yaşam olayları çocukların psikolojik iyilik halini tehlikeye sokabilmektedir. Psikolojik iyilik halinin kalıcılığ çocukların gelişimini olumlu yönde etkilemekteyken, yerinden edilme ve yaşam koşullarının kötüleşmesi çocukları olumsuz yönde etkilemektedir. Psikolojik iyilik hali ve mutluluk düzeyi yeterli olan çocuklar daha az gelişimsel risk altındadır. Çeşitli önlemler alınarak psikolojik iyilik 
hali korunan çocuklar, yeni topraklara daha kolay uyum sağlayabilmekte ve gelişim düzeylerine uygun potansiyellerini en üst seviyede geliştirebilmektedir (Abdul-Rıda \& Nauck, 2013).

İlgili alanyazın incelendiğinde; yurt dışında zorunlu göçün 10-14 yaş aralığındaki çocuklara etkilerinin incelendiği araştırmaların, zaman zaman yaşanan silahlı çatışma ve istikrarsızlıklar sonucu Yugoslavya, Bosna, Tibet ve Şili gibi ülkelere yapılan göçleri ele almakla birlikte (Ekblad, 2003; Hjern, Angel \& Hojern 1991; Kocijan-Hercigonja, Rijavec, Marusic \& Hercigonja, 1998; Servan-Schreiber, Le Lin \& Birmaher, 1998), ülke politikası çerçevesinde planlı göçmen alımı gerçekleştiren Hollanda, Finlandiya gibi çeşitli ülkelere yapılan göçlerin de ele alındığ1 (Rothe, Lewis, Castillo-Matos, Martinez, Busquets \& Martinez 2002; Sourander, 1998) görülmüştür. Ülkemizde yapılan araştırmalar incelendiğinde; terör olayları nedeniyle doğu illerimizde boşaltılan köylerden başka illere yapılan göçlerin çocuklara etkilerinin incelendiği araştırmalara rastlanmakla birlikte (Aker, 2006), zorunlu göçün çocuklara psikolojik etkilerinin incelendiği araştırmaların İstanbul, Gaziantep gibi Suriye uyruklu yabancıların yoğun olduğu illerde yürütüldüğü (Gez, 2018; Kuru, 2020; Özer, Şirin \& Oppedal, 2013; Şirin Rogers \& Şirin 2015; Uğurlu, 2015) anlaşılmış ve Ankara ilinde yapılan benzer bir araştırmanın bulunmadığı fark edilerek, Ankara ili sınırları içerisinde yaşayan ve zorunlu göçe maruz kalan çocukların psikolojik iyilik hallerinin incelenmesi yoluyla ilgili alanyazına katkı sunmak amaçlanmıştır.

Bu çerçevede, Ankara ili Altındağ ilçesi sınırları içinde yaşayan ve zorunlu göçe maruz kalan Suriye uyruklu çocuklarla yürütülen çalışmada aşağıdaki problem durumlarına cevap aranmıştır:

$\checkmark$ Zorunlu göçe maruz kalan çocukların yaşam doyumu nasıldır? Çocukların yaşam doyumu puanları cinsiyet, yaş ve öğrenim görülen sınıf değişkenlerine göre farklılık göstermekte midir?

$\checkmark \quad$ Yaşam doyumları düşük ve yüksek olarak belirlenen çocukların kendi psikolojik iyilik hallerine ilişkin değerlendirmeleri nasıldır?

\section{Yöntem}

\subsection{Araştırma Modeli}

$\mathrm{Bu}$ araştırma karma yöntem araştırma modellerinden açımlayıcı sıralı karma yöntem deseni ile gerçekleştirilmiştir. Açımlayıcı sıralı karma yöntem araştırmacının nicel bir aşamayı takiben nitel bir aşamayı izlediği bir çalışma yöntemidir. Bu yaklaşımda birinci aşamada nicel veri toplanır ve bulgular analiz edilir. İkinci aşamada ise nicel bulgulardan hareketle nitel araştırma gerçekleştirilir (Creswell, 2016; Creswell \& Clark, 2015). Araştırmanın nicel boyutunda genel tarama modellerinden betimsel çalışma deseni uygulanmıştır. Araştırmanın nitel boyutunda ise nitel araştırma modellerinden içsel durum desenine uygun bir uygulama gerçekleştirilmiştir. İçsel durum deseninde bir durumu aydınlatmak için duruma ilişkin özellikler derinlemesine ele alınır (Creswell, 2013; Johnson \& Christiansen, 2014; Karasar, 2013).

\section{2. Çalışma Grubu}

Araştırmanın nicel boyutunda çalışma grubu amaçlı örnekleme yöntemlerinden ölçüt örnekleme yöntemi ile belirlenmiştir (Büyüköztürk, 2008; Yıldırım \& Şimşek, 2016). Araştırmanın nicel boyutunda verilerin toplanması için ilk olarak Ankara İl Milli Eğitim Müdürlüğünden il genelindeki Suriye uyruklu öğrenci sayısı istenmiş ve Ankara ili genelinde 2017-2018 eğitim öğretim döneminde 5., 6., 7. ve 8. sinıfta öğrenim gören toplamda 1027 Suriye uyruklu öğrenci olduğu bildirilmiştir. Zaman, maliyet ve erişilebilirlik açısından yapılan değerlendirme 
sonucunda, Altındağ ilçesinde dört okul belirlenmiş ve okul idareleri ile görüşme yapılmıştır. Yapılan görüşme sonrasında Türkçe bilgisi yeterli olan, 5., 6., 7., 8. sınıfta öğrenim gören ve araştırmaya katılmada gönüllü olan toplam 96 çocuk seçilmiştir. Araştırmanın nicel boyutuna katılan çocukların demografik bilgileri Tablo 1'de verilmiştir:

Tablo 1. Araştırmanın Nicel Boyutuna Katılan Çocukların Demografik Bilgileri

\begin{tabular}{llcc}
\hline \multicolumn{2}{c}{ Değişkenler } & f & \% \\
\hline \multirow{2}{*}{ Cinsiyet } & K1z & 55 & 57.3 \\
& Erkek & 41 & 42.7 \\
\hline \multirow{4}{*}{ Yaş } & 11 & 17 & 17.7 \\
& 12 & 30 & 31.3 \\
& 13 & 27 & 28.1 \\
\multirow{3}{*}{ Ŏğrenim Görülen Sınıf } & 14 & 22 & 22.9 \\
& 5. Sinıf & 12 & 12.5 \\
& 6. Sinıf & 32 & 33.3 \\
\multirow{2}{*}{ Ebeveyn Durumu } & 8. Sinıf & 25 & 26.1 \\
& Birlikte yaşıyor & 27 & 28.1 \\
\hline Toplam & Ayrı yaşıor & 83 & 86.5 \\
& & 13 & 13.5 \\
\hline
\end{tabular}

Tablo 1'de görüldüğg̈ gibi, çocukların \%57,3'ü kı, \%42,7'si erkektir. Çocukların 17,7'si 11, \%31,3'ü 12, \%28,1'i 13 ve \%22,9'u 14 yaşındadır. Çocukların \%12,5'i 5. sinıfta, \%33,3'ü 6. sınıfta, \%26,1'i 7. sınıfta ve \%28,1'i 8. sınıfta öğrenim görmektedir. Çocukların \%86,5'i anne ve babasıyla birlikte yaşamaktayken, $\% 13,5$ 'i anne-babasından ayrı yaşamaktadır.

Araştırmanın nitel boyutunda çalışma grubu uç nokta durum örneklemesi çerçevesinde belirlenmiştir. Uç nokta durum örneklemesinde bir boyutun uç noktaları ya da aşırı değerlerini kapsayan durumlar belirlenip seçilir. Bu sayede daha zengin veri ortaya koyulur ve problem daha derinlemesine ele alınabilir (Christensen vd., 2015; Yıldırım \& Şimşek, 2016). Bu doğrultuda nicel boyuttan uygulaması gerçekleştirilen ÇÖYDÖ sonuçları incelenerek düşük orta ve yüksek puan grupları belirlenmiştir. Daha sonra ise ÇÖYDÖ’ den yüksek puan alan gruptaki ve düşük puan alan gruptaki çocuklardan dört kız dört erkek toplamda sekiz çocuk belirlenmiştir. Araştırmanın nitel boyutuna katılan çocukların demografik bilgileri Tablo 2'de verilmiştir:

Tablo 2. Araştırmanın Nitel Boyutuna Katılan Çocukların Demografik Bilgileri

\begin{tabular}{llcc}
\hline \multicolumn{1}{c}{ Katılımcı Kodu } & \multicolumn{1}{c}{ Cinsiyet } & Yaş & Sinıf Düzeyi \\
\hline DPK1 & Kiz & 14 & 7 \\
\hline DPK2 & Erkek & 13 & 6 \\
\hline DPK3 & Erkek & 13 & 6 \\
\hline DPK4 & K1z & 14 & 8 \\
\hline YPK1 & K1z & 12 & 7 \\
\hline YPK2 & Erkek & 12 & 6 \\
\hline YPK3 & K1z & 13 & 7 \\
\hline YPK4 & Erkek & 14 & 8
\end{tabular}

Tablo 2'de görüldüğü gibi, çocukların 4'ü kız 4'ü erkektir. Çocukların 3'ü 7. sinıfta, 3’ü 6 . sınıfta ve 2'si 8. sinıfta öğrenim görmektedir. Çocukların 3'ü 12, 3'ü 14 ve 2'si 13 yaşındadır. 


\subsection{Veri Toplama Araçları}

Bilgi Formu: Araştırmacı tarafından hazırlanmıştır ve çocukların yaş, cinsiyet, öğrenim görülen sınıf düzeyi ve maddi gelir seviyesi vb. bilgilerini içermektedir.

Çok Boyutlu Öğrenci Yaşam Doyumu Ölçeği (ÇÖYDÖ): Huebner (1994) tarafindan geliştirilmiş ve Çivitçi (2007) tarafından Türkçe'ye uyarlanmıştır. Ölçek 36 maddeden oluşmaktadır ve arkadaş, okul, çevre, aile, benlik alt boyutları ile bütüncül yaşam doyumu puanları hakkında bilgi vermektedir. 5'li likert tipindedir. İlkokul ikinci kademedeki çocuklara uygulanabilen ölçeğin hem genel yaşam doyumu puanı hem de arkadaş, okul, çevre, aile ve benlik alt boyutlarındaki test tekrar test güvenirliği $.70-.86$ ve iç tutarlık güvenirliği $.70-.85$ arasında değişmektedir (Çivitçi, 2007).

Yarı Yapılandırılmış Görüş̧me Formu: UNICEF tarafından 2013 yılında yayınlanan "Gelişmiş Ülkelerde Çocuk İyilik Hali Raporu" çerçevesinde çocukların maddi/fiziksel iyilik hali, sağlik ve güvenlik, eğitimsel iyilik hali, kişilerarası ilişki değerlendirmeleri, davranışlar ve riskler ile kendi mutluluk değerlendirmelerine ilişkin bilgiler edinilmesi amacıyla araştırmacı tarafından hazırlanmıştır. Hazırlanan sorular üç alan uzmanının görüşüne sunulduktan sonra alınan dönütler doğrultusunda düzeltmeler yapılmış ve Ankara İl Milli Eğitim Müdürlüğü Etik Kurulu'ndan alınan cümle düzeltme dönütleri birleştirilerek görüşme formuna son hali verilmiştir.

\subsection{Veri Toplama Süreci}

Çocuklara araştırma konusunda bilgi verildikten sonra ebeveynlerden izin alınması için Arapça ve Türkçe izin formları ebeveynlere gönderilmiştir. 103 form olumlu geri dönmüştür. ÇÖYDÖ uygulama sürecinde araştırmaya katılmaktan vazgeçen üç çocuk ve ölçme aracı uygulaması sonrası eksik bırakıldığ anlaşılan dört form araştırma kapsamı dışına çıkarılmış ve toplamda 96 çocuk araştırmanın nicel boyutuna alınmıştır.

Araştırmanın nitel boyutunda ise belirlenen sekiz çocuğa uygulama hakkında (görüşmenin içeriği, gizlilik, ebeveyn onamı ve araştırmadan istedikleri anda çekilebilme özgürlükleri hakkında) bilgi verilmiş ve ebeveynlerinin de izin vermesi halinde araştırmaya katılabilecekleri ifade edilmiştir. Bu aşamada da çocuk ve ebeveyn onamına başvurulmuş ve daha sonra görüşme aşamasına geçilmiştir.

\subsection{Verilerin Analizi}

Araştırmanın nicel boyutunda öncelikle verilerin normallik şartını sağlayıp sağlamadığına ilişkin Shapiro Wilk Testi yapılmıştır. Veri setinin cinsiyet (erkek p: ,397, kız p: ,294), yaş (11 yaş p: ,209, 12 yaş p: ,871, 13 yaş p: ,055, 14 yaş p: ,673) ve sınıf düzeyi (5. sınıf p: ,333, 6 . sınıf p: ,775, 7. sınıf p: ,618, 8. sınıf p: ,188) değişkenleri açısından normallik şartını sağladığı anlaşılmıştır. Bu nedenle verilerin analizinde parametrik testlerden Bağımsız Örneklem t Testi ve ANOVA Testi uygulanmıştır.

Araştırmanın nitel boyutunda ise çocuklarla yapılan görüşmelerden elde edilen veriler betimsel analiz yöntemi ile analiz edilmiştir. Görüşme dökümleri tümdengelimsel olarak analiz edilmiştir. Araştırma kapsamında ilgili alanyazın incelenmiş ve psikolojik iyilik hali kavramı bağlamında, maddi/fiziksel iyilik hali, sağlık ve güvenlik, eğitimsel iyilik hali, kişilerarası ilişki değerlendirmeleri, davranışlar ve riskler ile çocukların kendi mutluluk değerlendirmeleri temaları belirlenmiştir. Bu temalara uygun olarak sorulan soruların analizi sonrasında ortaya 
çıkan kodlar bu temalar altında toplanmıştır (Creswell, 2013; Glesne, 2013; Yıldırım \& Şimşek, 2016).

\subsection{Geçerlik ve Güvenirlik}

Araştırmanın nicel boyutunda güvenirliğin sağlanabilmesi için, ÇÖYDÖ uygulaması çocukların genel uyarılmışlık halleri göz önünde bulundurularak sabah erken saatler ile öğle yemeğinden hemen sonra yapılmamıştır. Araştırmaya katılma ölçütlerini sağlamayan hiçbir çocuk araştırmaya dahil edilmemiş ve çocuklardan elde edilen veriler analiz edilmeden önce araştırmacı ve bir uzman tarafından kontrol edilmiştir. Araştırmanın nicel boyutunda çocukların genel yaşam doyumu puanlarının iç tutarlık değerinin ,834 olduğu sonucuna ulaşılmıştır.

Araştırmanın nitel boyutunda güvenirliğin sağlanabilmesi için, araştırmacı ve bir uzman tarafından yazılı olarak kayıt altına alınan görüşme dökümleri ayrı ayrı analiz edilmiştir. Daha sonra analiz sonuçları bütünleştirmiş ve her iki araştırmacı çocukların verdikleri cevapları kategorize etmiştir. Araştırmanın nitel boyutunun güvenirliğinin, Güvenirlik=Görüş Birliği/ Görüş Birliği + Görüş Ayrılığ1 formülü çerçevesinde .94 olduğu sonucuna ulaşılmıştır (Miles \& Huberman, 1994).

\subsection{Etik Kurul İzni}

Yapılan bu çalışmada "Yükseköğretim Kurumları Bilimsel Araştırma ve Yayın Etiği Yönergesi” kapsamında uyulması belirtilen tüm kurallara uyulmuştur. Araştırma Göç Uzmanlığ 1 tezinden üretilmiş olup veriler 2020 yılı öncesinde toplanmıştır. Araştırmanın yürütülebilmesi için Göç İdaresi Genel Müdürlüğü ve Ankara İl Milli Eğitim Müdürlüğünden yasal izinler alınmıştır.

\section{Bulgular}

\section{1. Çocukların ÇÖYDÖ’den Aldıkları Puanların Cinsiyet, Yaş ve Öğrenim Görülen Sınıf Değişkenlerine Göre Karşılaştırılması}

İlk olarak "Zorunlu göçe maruz kalan çocukların yaşam doyumu nasıldır? "sorusuna cevap aranmıştır. Araştırmanın nicel boyutuna katılan çocuklara ilişkin temel istatistikler Tablo 3'te verilmiştir:

Tablo 3. ÇÖYDÖ Temel İstatistikler

\begin{tabular}{lccc}
\hline ÇÖYDÖ Puanı & $\mathbf{n}$ & $\overline{\mathbf{X}}$ & SS \\
\hline K1z & 55 & 115,600 & 14,460 \\
\hline Erkek & 41 & 113,829 & 12,567 \\
\hline 11 & 17 & 115,411 & 13,233 \\
\hline 12 & 30 & 114,433 & 14,419 \\
\hline 13 & 27 & 115,444 & 12,671 \\
\hline 14 & 22 & 114,227 & 13,683 \\
\hline 5. sinıf & 12 & 112,500 & 112,500 \\
\hline 6. sinıf & 32 & 113,093 & 113,093 \\
\hline 7. sinif & 25 & 118,280 & 118,280 \\
\hline 8. sinif & 27 & 114,777 & 114,777 \\
\hline Toplam & 96 & 114,843 & 13,3640 \\
\hline & & &
\end{tabular}

Tablo 3'te cinsiyet değişkenine göre ÇÖYDÖ'den elde edilen puanların aritmetik ortalamaları incelendiğinde; kızların $\overline{\mathrm{X}}$ : 115,600, erkeklerin $\overline{\mathrm{X}}$ : 113,829 puan aldıkları görülmektedir. 
Yaşlara göre ÇÖYDÖ'den elde edilen puanların aritmetik ortalamaları incelendiğinde; 11 yaş çocukların $\overline{\mathrm{X}}: 115,411,12$ yaş çocukların $\overline{\mathrm{X}}: 114,433,13$ yaş çocukların $\overline{\mathrm{X}}: 115,444$ ve 14 yaş çocukların $\bar{X}: 114,227$ puan aldıkları ve sınıf düzeyi değişkenine göre ÇÖYDÖ’den elde edilen puanların aritmetik ortalamaları incelendiğinde, 5. sınıf çocuklarının $\overline{\mathrm{X}}: 112,500$, 6. sınıf çocuklarının $\overline{\mathrm{X}}: 113,093$, 7. sınıf çocuklarının $\overline{\mathrm{X}}: 118,280$ ve 8 . sınıf çocuklarının $\overline{\mathrm{X}}=114,777$ puan aldıkları görülmektedir. Yani araştırmaya katılan çocukların genel yaşam doyumu puanlarının aritmetik ortalamalarının iyi seviyede olduğu anlaşılmaktadır.

Daha sonra "Çocukların yaşam doyumu puanları cinsiyet, yaş ve sınıf düzeyi değişkenlerine göre farklılık göstermekte midir?" sorusuna cevap aranmıştır. İlk olarak çocukların yaşam doyumu puanlarının cinsiyet değişkenine göre farklılaşıp farklılaşmadığ testi ile incelenmiş ve sonuçlar Tablo 4'te verilmiştir:

Tablo 4. Cinsiyet Değişkeni Bağımsız Örneklem t Testi Sonuçları

\begin{tabular}{|c|c|c|c|c|c|}
\hline Cinsiyet & $\mathrm{n}$ & $\overline{\mathbf{X}}$ & SS & $\mathbf{t}$ & $\mathbf{p}$ \\
\hline Erkek & 41 & 113,829 & 14,460 & \multirow{2}{*}{,- 640} & \multirow{2}{*}{,524 } \\
\hline $\mathrm{K} 1 \mathrm{z}$ & 55 & 115,600 & 12,567 & & \\
\hline
\end{tabular}

Tablo 4'te cinsiyet değişkenine göre ÇÖYDÖ'den elde edilen puanların aritmetik ortalamaları incelendiğinde; kızların görece daha yüksek puan aldığg görülmekle birlikte, $t$ testi sonuçları göz önünde bulundurulduğunda, cinsiyet değişkenine göre yaşam doyumu puanlarında istatistiksel açıdan anlamlı bir farklılık olmadığı sonucuna ulaşılmıştır.

Çocukların yaşam doyumu puanlarının yaş değişkenine göre farklılaşıp farklılaşmadığı ANOVA testi ile incelenmiş ve sonuçlar Tablo 5'te verilmiştir:

Tablo 5. Yaş Değişkeni ANOVA Testi Sonuçları

\begin{tabular}{|c|c|c|c|c|c|c|c|c|}
\hline Yaş & $\mathbf{n}$ & $\overline{\mathbf{X}}$ & SS & $\begin{array}{c}\text { Varyansın } \\
\text { Kaynağı }\end{array}$ & KT & sd & $\mathbf{f}$ & $\mathbf{p}$ \\
\hline 11 & 17 & 115,4118 & 13,23376 & Gruplar arası & 28,642 & 3 & \multirow{5}{*}{052} & \multirow{5}{*}{984} \\
\hline 12 & 30 & 114,4333 & 14,41906 & Grup içi & 16938.015 & 92 & & \\
\hline 13 & 27 & 115,4444 & 12,67139 & Toplam & 16966,656 & 95 & & \\
\hline 14 & 22 & 114,2273 & 13,68326 & & & & & \\
\hline Top & 96 & 114,8438 & 13,36400 & & & & & \\
\hline
\end{tabular}

Tablo 5'te yaşlara göre ÇÖYDÖ'den elde edilen puanların aritmetik ortalamaları incelendiğinde, araştırmaya katılan çocukların yaş değişkenine göre yaşam doyumu puanları arasında istatistiksel açıdan anlamlı bir farklılık olmadığı sonucuna ulaşılmıştır.

Çocukların yaşam doyumu puanlarının sınıf düzeyi değişkenine göre farklılaşıp farklılaşmadığı ANOVA testi ile incelenmiş ve sonuçlar Tablo 6'da verilmiştir:

Tablo 6. Sınıf Düzeyi Değişkeni ANOVA Testi Sonuçları

\begin{tabular}{|c|c|c|c|c|c|c|c|c|}
\hline $\begin{array}{l}\text { Sinıf } \\
\text { Düzeyi }\end{array}$ & $\mathbf{n}$ & $\overline{\mathbf{X}}$ & SS & $\begin{array}{c}\text { Varyansın } \\
\text { Kaynağı }\end{array}$ & KT & sd & f & $\mathbf{p}$ \\
\hline 5 & 12 & 112,5000 & 14,60075 & Gruplar arası & 459 & 3 & \multirow{5}{*}{052} & \multirow{5}{*}{984} \\
\hline 6 & 32 & 113,0938 & 13,35703 & Grup içi & 16507 & 92 & & \\
\hline 7 & 25 & 118,2800 & 12.97279 & Toplam & 16966 & 95 & & \\
\hline 8 & 27 & 114,7778 & 13,29064 & & & & & \\
\hline Top & 96 & 114,8430 & 13,36400 & & & & & \\
\hline
\end{tabular}


Tablo 6'da sınıf düzeyi değişkenine göre ÇÖYDÖ'den elde edilen puanların aritmetik ortalamaları incelendiğinde, 7. sınıf çocuklarının diğer sınıf düzeylerindeki çocuklara göre daha yüksek puan aldığ 1 görülmekle birlikte, sınıf düzeyi değişkenine göre yaşam doyumu puanlarında istatistiksel açıdan anlamlı bir farklılık olmadığı sonucuna ulaşılmıştır.

\section{2. Çocukların Kendi Psikolojik İyilik Hallerine İlişskin Değerlendirmelerinin İncelenmesi}

$\mathrm{Bu}$ kısımda ise "Yaşam doyumları düşük ve yüksek olarak belirlenen çocukların kendi psikolojik iyilik hallerine ilişkin değerlendirmeleri nasıldır?" sorusuna cevap aranmış ve sonuçlar maddi-fiziksel iyilik hali, sağlık ve güvenlik durumu, eğitimsel- iyilik hali, kişilerarası ilişki durumu, davranışlar ve riskler durumu ile çocukların kendi mutluluk değerlendirmeleri temaları altında sunulmuştur.

\subsubsection{Maddi-Fiziksel İyilik Hali}

Çocukların kendi maddi-fiziksel iyilik haline ilişkin değerlendirmeleri "ailelerinin gelir durumu" ve "çocukların ihtiyaçlarının karşılanma durumu" alt kategorileri çerçevesinde incelenmiştir. Çocukların "Ailenin aylık kazancı yaklaşık olarak ne kadardır? sorusuna verdiği cevaplar Tablo 7'de verilmiştir:

Tablo 7. Ailelerin Gelir Durumu*

\begin{tabular}{lcc}
\hline ÇÖYDÖ Puanı & $\mathbf{0 - 1 7 0 0 ~ T L}$ & $\mathbf{1 7 0 0}$ ve üstü \\
\hline Düşük & 3 & 1 \\
\hline Yüksek & 3 & 1 \\
\hline$*$
\end{tabular}

*Araştırma yapıldığında asgari ücret $1650 \mathrm{Tl}$ civarındadır.

Tablo 7'de görüldüğü gibi, ÇÖYDÖ'den düşük puan alan gruptaki üç çocuk ile yüksek puan alan gruptaki 3 çocuk ailelerinin aylık gelirinin 0-1700 TL arasında olduğunu, birer çocuk ise ailesinin aylık gelirinin 1700 TLve üstü olduğunu ifade etmiştir.

Çocukların "Karşılamakta zorlandığın ihtiyaçların var mı?” sorusuna verdiği cevaplar Tablo 8'de verilmiştir:

Tablo 8. Çocukların İhtiyaçlarının Karşılanma Durumu

\begin{tabular}{lcc}
\hline ÇÖYDÖ Puanı & Evet & Hayır \\
\hline Düsük & 4 & - \\
\hline Yüksek & 3 & 1 \\
\hline
\end{tabular}

Tablo 8'de görüldüğü gibi, çocukların büyük kısmının (n: 7) karşılamakta zorlandıkları ihtiyaçları bulunmaktadır. DPK1 "elbise almakta zorlanıyorum, farklı elbiselerimin olmasını isterdim" biçiminde bu durumu ifade ederken, DPK3 "bazen oyun oynarken topum patlyor, babam kızıyor ve almıyor. Topum patladı̆̆ için yenisini alamıyorum", YPK4 "bazen istediğim şeyleri almakta zorlaniyorum, örneğin futbol topu almak istiyorum" ve DPK2 "birçok ihtiyacımı abilerim alıyor ama bilgisayarım yok almak istiyorum, alamıyorum" biçiminde bazı ihtiyaçlarının bulunduğunu belirtmiştir. YPK3 babasının tüm ihtiyaçlarını karşıladığını "babam tüm ihtiyaçlarımı alıyor" biçiminde ifade ederken, üç çocuk ise sadece ihtiyaçlarını karşılayamadıklarını ifade etmiş, ihtiyaçlarına ilişkin ek bir açıklama yapmamıştır. 


\subsubsection{Sağllk ve Güvenlik Durumu}

Çocukların sağlık ve güvenlik durumuna ilişkin değerlendirmeleri "kalıcı etkileri bulunan tıbbi işleme maruz kalma" ve "çocukların korku kaynakları" alt kategorileri çerçevesinde incelenmiştir. Çocukların "hastanede kalıcı etkileri bulunan tıbbi işlem gördün mü?" sorusuna verdiği cevaplar Tablo 9'da verilmiştir:

Tablo 9. Kalıcı Etkileri Bulunan Tıbbi Işleme Maruz Kalma

\begin{tabular}{lcc}
\hline ÇÖYDÖ Puanı & Evet & Hayır \\
\hline Düşük & 3 & 1 \\
\hline Yüksek & 1 & 3 \\
\hline
\end{tabular}

Tablo 9'da görüldüğ̈̈ gibi, ÇÖYDÖ'den düşük puan alan gruptaki çocuklardan DPK2 “10 yaşındayken Suriye'de ameliyat oldum ama ne ameliyatı olduğunu bilmiyorum, ıll yani şuradan”, DPK3 "1 yaşındayken böbrek hastalığı yaşamışım. Annem söyledi 1 yıl hastanede yatmışım, çok koştuğumda böbreklerim ağrıyor”, DPK4 "bademcik ameliyatı geçirdim, ameliyattan sonra yemek yeme zorluğu çektim, boğazım ağrıd ve sesim değişti" biçiminde kalıcı etkileri bulunan tıbbi bir işleme maruz kaldığını ifade ederken, DPK1 herhangi bir kalıcı etkileri bulunan tıbbi bir işleme maruz kalmadığını ifade etmiştir. Diğer yandan ÇÖYDÖ’den yüksek puan alan gruptaki çocuklardan YPK3 "7 yaşındayken kalp ameliyatı geçirdim ve hala kalp rahatsızlı̆̆ım var" ve YPK4 "5 yaşındayken göz ameliyatı geçirdim” biçiminde kalıcı etkileri bulunan tıbbi bir işleme maruz kaldığını ifade etmiştir. YPK1 ve YPK2 kalıc1 etkileri bulunan herhangi bir tıbbi işleme maruz kalmadıklarını ifade etmiştir.

Çocukların "Yaşadığın yerlerde seni korkutan bir şey var mı?" sorusuna verdiği cevaplar Tablo 10'da verilmiştir:

Tablo 10. Çocukların Korku Kaynakları

\begin{tabular}{lcc}
\hline ÇÖYDÖ Puanı & $\begin{array}{c}\text { Yakın Fiziksel } \\
\text { Çevre Kaynaklı }\end{array}$ & Bireysel Yaşantı Kaynaklı \\
\hline Düşük & 3 & 1 \\
\hline Yüksek & - & - \\
\hline
\end{tabular}

Tablo 10'da görüldüğü gibi, ÇÖYDÖ'den düşük puan alan gruptaki üç çocuk yaşadıkları mahalle şartları ile ilgili korkularının olduğunu belirtmişlerdir. DPK4 "okul evden uzak ve mahalle issiz, çok fazla köpek var ve ben onlardan korkuyorum", DPK3 "yaşadığım mahallede köpek çok, onlar bazen saldırıyor, ben onlardan korkuyorum”, DPK2 “... yaşadığım mahallede çok köpek var" biçiminde bu durumu ifade etmiştir. DPK1 ise yaşadığı bir olayın olas1 sonuçlarının kendisini korkuttuğunu "geçen hafta arkadaşımdan bir şey aldım, o da bozuldu, o da benden parasını istedi, bende para yok, anne-babama söyleyecek diye çok korktum" biçiminde ifade etmiştir. Diğer yandan ÇÖYDÖ'den yüksek puan alan gruptaki çocukların tamamı bu soruya "hayır" cevabını vermiştir.

\subsection{3. Ĕgitimsel İyilik Hali}

Çocukların kendi eğitimsel iyilik hallerine ilişkin değerlendirmeleri "okula devamsızlık durumları ve nedenleri" ve "ders kitabı haricinde kitaba sahip olma durumu" alt kategorileri çerçevesinde incelenmiştir. Çocukların "Geçen dönem toplamda kaç gün okula gelmedin? ve "Okula gelmeme sebebin neydi?" sorularına verdiği cevaplar Tablo 11 ve Tablo 12'de verilmiştir: 
Tablo 11. Okula Devamsızlık Durumları

\begin{tabular}{lccc}
\hline ÇÖYDÖ Puanı & $\mathbf{0 - 5}$ gün & $\mathbf{5 - 1 0}$ gün & $\mathbf{1 0 +}$ gün \\
\hline Düşük & 3 & - & 1 \\
\hline Yüksek & 3 & 1 & - \\
\hline
\end{tabular}

Tablo 11'de görüldüğü gibi, ÇÖYDÖ'den düşük puan alan gruptaki üç çocuk 5 gün ve daha az, bir çocuk ise 10 gün ve daha fazla devamsızlık yaptığını, ÇÖYDÖ’den yüksek puan alan gruptaki üç çocuk 5 gün ve daha az, bir çocuk ise 5-10 gün aralığında devamsızlık yaptığını ifade etmiştir.

Çocukların okula devamsızlık nedenleri Tablo 12'de verilmiştir:

Tablo 12. Devamsızlık Nedenleri*

\begin{tabular}{lccc}
\hline $\begin{array}{l}\text { ÇÖYDÖ } \\
\text { Puanı }\end{array}$ & Hastalık & $\begin{array}{c}\text { Ebeveyn/Yetişkin } \\
\text { Rolü Üstlenme }\end{array}$ & $\begin{array}{c}\text { Keyfi } \\
\text { Devamsızlık }\end{array}$ \\
\hline Düşük & 3 & 2 & 1 \\
\hline Yüksek & 4 & 1 & 2 \\
*Çocuklar tarafidan birden fazla devamsılılı nedeni belirtilmiştir. &
\end{tabular}

Tablo 12'de görüldüğü gibi, ÇÖYDÖ'den düşük puan alan gruptaki çocuklar devamsızlık nedenleri olarak hastalık, ebeveyn/yetişkin rolü üstlenme ve keyfi gelmeme durumlarını dile getirmişlerdir. DPK3 "1 gün çok hastaydım. 2 gün ise bizi İstanbul'a gezmeye götürdüler", DPK4 "3 gün evde hasta yattım. 1 gün ise kardeşim hastaydl ve ona baktım", DPK2 "2 gün hasta oldum, evdeydim. 2 gün de Suriye'den akrabalarımı geldiği için anneme yardım ettim" biçiminde bu durumu ifade etmiştir. DPK1 devam etmeme sebebini "Bazen annem teyzemi hastaneye götürüyor ve ben de engelli amcalarıma bakıyorum. Teyzem kanser hastast..." biçiminde ifade etmiştir. Diğer yandan ÇÖYDÖ'den yüksek puan alan gruptaki çocuklardan YPK3 "kalp rahatsılığım ile ilgili kontrol için doktora gittim", YPK1 "3 gün hasta oldum, 1 gün ise babamla Ulus'a gittik", YPK4 "2 gün hasta olduğum için evde dinledim. 3 gün ise canım okula gelmek istemedi" biçiminde devamsızlık nedenlerini ifade etmiştir. YPK2 ise toplamda 10 gün devamsızlık yaptığını ve devamsızlık sebeplerini, "5 gün hastaydım, diğer 5 gün gelmek istemedim" biçiminde ifade etmiştir.

Çocukların "Ders kitapların haricinde herhangi bir kitabın var mı?" sorusuna verdiği cevaplar Tablo 13'te verilmiştir:

Tablo 13. Ders Kitabı Haricinde Kitaba Sahip Olma Durumu

\begin{tabular}{lcc}
\hline ÇÖYDÖ Puanı & Evet & Hayır \\
\hline Düşük & 1 & 3 \\
\hline Yüksek & 1 & 3 \\
\hline
\end{tabular}

Tablo 13’te görüldüğü gibi, ÇÖYDÖ'den düşük puan alan gruptaki DPK2 “evet, ama kitabımın adını bilmiyorum" cevabını verirken diğer üç çocuk "hayır" cevabını vermiştir. Benzer biçimde ÇÖYDÖ’den yüksek puan alan gruptaki YPK1 "evet kitabımın adı Rapunzel" cevabını verirken, 3 çocuk "hayır" cevabını vermiştir.

\subsubsection{Kişilerarası İlişki Durumu}

Çocukların kendi kişiler arası ilişki durumuna ilişkin değerlendirmeleri "aile üyeleri ile ilişkiler" ve "arkadaşlar ile ilişkiler" alt kategorileri çerçevesinde incelenmiştir. Çocuklara "Ailende en 
çok kiminle vakit geçirmeyi seviyorsun ve nasıl vakit geçiriyorsun?" sorusuna verdiği cevaplar Tablo 14'te verilmiştir:

Tablo 14. Aile Üyeleri İle İlişkiler

\begin{tabular}{lccc}
\hline ÇÖYDÖ Puanı & Anne & Baba & Kardeşler \\
\hline Düşük & 2 & 1 & 1 \\
\hline Yüksek & 2 & - & 2 \\
\hline
\end{tabular}

Tablo 14'te görüldüğü gibi, ÇÖYDÖ'den düşük puan alan gruptaki DPK3 “...bazen annemle telefondan dizi izliyoruz", DPK2 "...annemle film izlemeyi seviyorum” biçiminde "annesi” ile, DPK4 "...babam ile akşamları Tv seyrediyorum" biçiminde "babası" ile, DPK1 “...tüm günümü kardeşim ile geçiriyorum, her şeyi onunla birlikte yapıyoruz" biçiminde "kardeşi” ile vakit geçirmekten hoşlandığını ifade etmiştir. ÇÖYDÖ'den yüksek puan alan gruptaki "YPK2 "...annemle akşamlar dizi izliyoruz", "YPK4 "...anneme ev işlerinden yardim ediyorum" biçiminde "annesi” ile, YPK1 “...kardeşimle oyunlar oynuyoruz”, YPK3 “...kardeşim ile dışarda vakit geçiriyorum" biçiminde "kardeşi”" ile vakit geçirmekten hoşlandığını ifade etmiştir.

Çocukların “Arkadaşların ile ilişkilerin nasıldır?" sorusuna verdiği cevaplar Tablo 15 'te verilmiştir:

Tablo 15. Arkadaşlar İle İlişkiler

\begin{tabular}{lccc}
\hline ÇÖYDÖ Puanı & $\begin{array}{c}\text { Birlikte } \\
\text { Oynamama- } \\
\text { Konuşmama }\end{array}$ & Kavga Etme & $\begin{array}{c}\text { Sorun } \\
\text { Yaşamama }\end{array}$ \\
\hline Düşük & 1 & 2 & 1 \\
\hline Yüksek & - & 1 & 3 \\
\hline
\end{tabular}

Tablo 15'te görüldügüü gibi, "ÇÖYDÖ’den düşük puan alan gruptaki DPK1 “Türk arkadaşlarımla aramı iyi değil, benimle oynamıyorlar ve konuşmuyorlar, ama Suriyeli arkadaşlarım iyi", DPK2 "Türklerle kavga ediyoruz ama Suriyelilerle kavga etmiyoruz", biçiminde Türk akranları ile anlaşmazlıklar yaşadıklarını belirtmiştir. DPK3 "bazen kavga ediyoruz ama çoğunlukla aramız iyi" biçiminde arkadaş ilişkilerinin iyi olduğunu, DPK4 "çok iyi çünkü arkadaşlarımla sorun yaşamıyorum" biçiminde arkadaş ilişkilerinden memnun olduğunu belirtmiştir. Diğer yandan, ÇÖYDÖ’den yüksek puan alan gruptaki YPK2 "kavga etmiyorum ve iyi vakit geçiriyorum”, YPK1 "arkadaşlarımla hiçbir problem yaşamıyorum”, YPK3 "bir sorun olduğunda konuşup çözüyoruz" ve YPK4 " arkadaşlarımla iyi vakit geçiriyoruz" biçiminde arkadaşl1k ilişkilerinden memnun olduğunu ifade etmiştir.

\subsubsection{Davranıșlar ve Riskler Durumu}

Çocukların iyilik hallerini tehlikeye sokabilecek risk unsurlarına ilişkin değerlendirmeleri "sabah, öğlen ve akşam ögünlerini kaçırma durumu" ve "son bir yılda şiddet içeren bir olayla karşılama durumu" alt kategorileri çerçevesinde incelenmiştir. Çocukların "bir şeyler yemeden geçirdiğin öğünler oldu mu?" sorusuna verdiği cevaplar Tablo 16 ve Tablo 17'de verilmiştir: 
Tablo 16. Sabah, Öğlen ve Akşam Öğünlerini Kaçırma Durumu

\begin{tabular}{lccc}
\hline \multicolumn{1}{c}{ ÇÖYDÖ Puanı } & & Evet & Hayır \\
\hline \multirow{3}{*}{ Düşük } & Sabah & 4 & - \\
\cline { 2 - 4 } & Öğlen & 4 & - \\
\cline { 2 - 4 } & Akşam & - & 4 \\
\hline \multirow{3}{*}{ Yüksek } & Sabah & 2 & 2 \\
\cline { 2 - 4 } & Öğlen & 1 & 3 \\
\cline { 2 - 4 } & Akşam & - & 4 \\
\hline
\end{tabular}

Tablo 16'da görüldüğü gibi, ÇÖYDÖ'den düşük puan alan gruptaki çocuklar sabah ve öğlen ögünlerini çeşitli sebeplerle birşeyler yemeden geçirdiklerini fakat akşam öğününü kaçırmadıklarını belirtmiştir. DPK1 "evde kahvaltı yapmiyorum, ...öğlen ise yemek yiyemiyorum, akşamları tüm aile toplanıp yemek yiyoruz", DPK4 "bazen kahvaltı yapmiyorum,... öğlen ise okulda yiyemiyorum ama akşamları yiyorum”, DPK3 "ben kahvaltı yapmam. Okulda öğlenleri yemek yiyemiyorum, .... Her akşam yemek yiyorum”, DPK2 "evde kahvalt yapmiyorum, okulda da yemek yemiyorum. Akşamları annem, babam abilerim ile birlikte yemek yiyoruz" biçiminde bu durumu ifade etmiştir. ÇÖYDÖ'den yüksek puan alan gruptaki çocuklardan, YPK4 "yaklaşık olarak $3 \mathrm{kez}$ kahvaltı yapmadan okula geldim.... öğle vakitlerinde ise çoğunlukla simit yiyorum. Her akşam yemek yiyorum" ve YPK3 "2-3 kez öğün yapamadım, ... öğlen karnımı doyuramadım, akşam yemeklerinde ise ögün kaçırmadım" şeklinde ara sıra kahvaltı yapmadıklarını belirtmiştir. YPK2 "herhangi bir öğünü kaçırmadım, her sabah kahvaltı yapıyorum, öğlen yemeğimi evden getiriyorum, ayrıca her akşam yemek yiyorum” biçiminde hiçbir öğünü kaçırmadığını, YPK1 ise " 5-6 kez ögün yapamadım iki gün evden öğlen yemeği için bir şey getiremedim. Ama akşam yemeklerini aksatmiyorum" biçiminde bazen öğlen yemek yiyemediğini fakat akşam öğünlerini kaçırmadığını ifade etmiştir.

Çocukların öğün kaçırma sebeplerine ilişkin bilgiler Tablo 17'de verilmiştir:

Tablo 17. Çocukların Öğünleri Kaçırma Sebepleri

\begin{tabular}{cccc}
\hline $\begin{array}{c}\text { ÇÖYDÖ } \\
\text { Puanı }\end{array}$ & Öğünler & $\begin{array}{c}\text { Kendi İsteğiyle } \\
\text { Yememe }\end{array}$ & $\begin{array}{c}\text { Kendi İsteği Dışında } \\
\text { Yiyememe }\end{array}$ \\
\hline \multirow{3}{*}{ Düşük } & Sabah & 4 & - \\
\cline { 2 - 4 } & Öğlen & 1 & 3 \\
\cline { 2 - 4 } & Akşam & - & - \\
\hline \multirow{2}{*}{ Yüksek } & Sabah & 1 & 3 \\
\cline { 2 - 4 } & Öğlen & 1 & - \\
\cline { 2 - 4 } & Akşam & - & \\
\hline
\end{tabular}

Tablo 17'de görüldüğü gibi, ÇÖYDÖ'den düşük puan alan gruptaki çocuklardan; DPK1 "evde kahvaltı yapmiyorum, öğlen ise yemek yiyemiyorum,", DPK4 “...sabahlar canım istemiyor, bazen de okula hazırlanmak zorunda olduğum için yiyemiyorum.", DPK3 "sadece süt içip okula geliyorum ben kahvaltı yapmam.", DPK2 "evde kahvalt yapmiyorum, okulda da yemek yemiyorum." biçiminde öğünleri kaçırma sebeplerini ifade etmiştir. Diğer yandan ÇÖYDÖ’den yüksek puan alan gruptaki çocuklardan, YPK2 "herhangi bir öğünü kaçırmadım," biçiminde hiçbir ögünü kaçırmadığını ifade ederken, YPK4 “... okula geç kaldığım için kahvaltı yapamadım ve hızlıca giyinip çıktım.”, YPK3 “... harçlığım olmadı̆̆ı için karnımı doyuramadım, kahvaltılarda annem uyanamadı ve hazırlamadı", YPK1 “...iki gün evden öğlen yemeği için bir şey getiremedim. $2-3 \mathrm{kez}$ de dişim ă̆rıdiğı için yiyemedim. Diğerini hatırlamıyorum. Ama akşam yemeklerini aksatmıyorum" biçiminde ögünleri kaçırma sebeplerini ifade etmişlerdir. 
Çocukların "Son 1 yılda evde, mahallede ya da okulda şiddet içeren bir olayla karşılaştın mı?" sorusuna verdiği cevaplar Tablo 18'de verilmiştir:

Tablo 18. Son Bir Yılda Şiddet İçeren Bir Olayla Karşılama Durumu

\begin{tabular}{lccc}
\hline $\begin{array}{l}\text { ÇÖYDÖ } \\
\text { Puanı }\end{array}$ & Şiddetle Karşılaş̧mama & Fiziksel Şiddet & Sözel ve Fiziksel Şiddet \\
\hline Düşük & 2 & 1 & 1 \\
\hline Yüksek & 1 & 1 & 2 \\
\hline
\end{tabular}

Tablo 18'de görüldüğü gibi, ÇÖYDÖ'den düşük puan alan gruptaki iki çocuk bu soruya "hayır" cevabını verirken, iki çocuk ise fiziksel şiddet içeren bir olayla karşılaştığını belirtmiștir. DPK1 "Bir kere arkadaşımla kavga ettim" biçiminde fiziksel şiddet olayıyla karşılaştığını, DPK3 "bir kez Türk ögrenci beni düşürdü ve eşyalarımı aldı. Öğretmene şikayet ettim ve kavga ettim" biçiminde hem fiziksel hem de sözel şiddet içeren bir olayla karşılaştığını ifade etmiştir. ÇÖYDÖ’den yüksek puan alan gruptaki çocuklardan YPK3 "hayır" cevabını verirken, YPK1 "2 ay önce mahallede Türk ve Suriyeli çocuklar arasında kavga çıktl, daha sonra onların anneleri ve babaları da kavga etti" ve YPK4 "geçen hafta bu Suriyeli diyerek bazı çocuklar beni gösterdi. Ben de klzdim ve onlarla kavga ettik” biçiminde sözel ve fiziksel şiddet içeren bir olayla karşılaştığını, YPK2 "5 ay önce okul bahçesinde kardeşim ve arkadaşımla gezerken 5 çocuk geldi bana vurdu ben de ögretmene şikayet ettim" biçiminde fiziksel şiddet olayıyla karşılaştığını ifade etmiştir.

\subsection{6. Çocukların Kendi Mutluluk-Uyum Değerlendirmeleri}

Çocukların kendi mutluluk-uyum değerlendirmeleri "zorlukla karşılaşma durumu" ve "mutluluk değerlendirmesi" alt kategorileri çerçevesinde incelenmiştir. Çocukların "Göç ettikten sonra zorluklarla karşılaştın mı?” sorusuna verdiği cevaplar Tablo 19'da verilmiştir.

Tablo 19. Zorlukla Karşılaşma Durumu

\begin{tabular}{lccc}
\hline ÇÖYDÖ Puanı & $\begin{array}{c}\text { Problemle } \\
\text { Karşılaşmama }\end{array}$ & $\begin{array}{c}\text { Sosyal İlişki } \\
\text { Problemi }\end{array}$ & $\begin{array}{c}\text { İletişim } \\
\text { Problemi }\end{array}$ \\
\hline Düsük & 3 & 1 & - \\
\hline Yüksek & 2 & 1 & 1 \\
\hline
\end{tabular}

Tablo 19'da görüldüğü gibi, ÇÖYDÖ'den düşük puan alan gruptaki üç çocuk bu soruya "hayır" cevabını verirken, DPK4 ise yaşadığ1 sosyal ilişki problemini "Türk arkadaşlarımız bizi dışlıyor" biçiminde ifade etmiştir. ÇÖYDÖ’den yüksek puan alan gruptaki iki çocuk bu soruya "hayır" cevabını verirken, YPK1 sosyal ilişki problemi yaşadığını, "Türk arkadaşlarımızla bizim aramızda bazen yașadığımız kavgalar hariç başka bir problem yok" biçiminde ve YPK 2 ise iletişim problemi yaşadığını, "dil problemi nedeniyle arkadaşlarımla bazen anlaşamıyorum" biçiminde ifade etmiştir.

Çocukların “ Mutluluğunu genel olarak değerlendirdiğinde kendini hangi kategoriye koyarsın?" sorusuna verdiği cevaplar Tablo 20'de ve mutsuzluk kaynakları Tablo 21'de verilmiştir:

Tablo 20. Çocukların Kendi Mutluluk Düzeylerine İlişkin Değerlendirmeleri

\begin{tabular}{lccc}
\hline ÇÖYDÖ Puanı & Mutsuz & Orta & Mutlu \\
\hline Düşük & 1 & 3 & - \\
\hline Yüksek & - & 1 & 3 \\
\hline
\end{tabular}


Tablo 20'de görüldüğü gibi, "ÇÖYDÖ'den düşük puan alan gruptaki bir çocuk kendisini mutsuz olarak, üç çocuk ise mutluluk düzeyini orta seviye olarak nitelendirmiştir. ÇÖYDÖ’den yüksek puan alan gruptaki bir çocuk kendi mutluluk seviyesini orta seviye olarak, üç çocuk kendisini mutlu olarak nitelendirmiştir.

Çocukların mutsuzluk kaynaklarına ilişkin bilgiler Tablo 21'de verilmiştir:

Tablo 21. Mutsuzluk Kaynakları

\begin{tabular}{lccc}
\hline ÇÖYDÖ Puanı & $\begin{array}{c}\text { Dışlanmış } \\
\text { Hissetme }\end{array}$ & $\begin{array}{c}\text { Savaş/Zorunlu } \\
\text { Göç }\end{array}$ & $\begin{array}{c}\text { Arkadaş } \\
\text { Bulamama }\end{array}$ \\
\hline Düşük & 2 & 2 & - \\
\hline Yüksek & - & - & 1 \\
\hline
\end{tabular}

Tablo 21'de görüldüğü gibi, ÇÖYDÖ'den düşük puan alan gruptaki DPK1 “çünkü Suriye'den taşınmak zorunda olduğum için ve amcalarım engelli olduğu için üzülüyorum" ve DPK2 "Suriye'de savaş var. Dedem, anneannem, amcam ve dayım hala Suriye'deler. Buraya gelmek istiyorlar ama gelemiyorlar. Ben de onlara bir şey olacak diye korkuyorum" biçiminde savaş ve zorunlu göçü temel mutsuzluk kaynağı olarak ifade etmiş, DPK3 "Türkler bize kötü davranıyor ve bizimle konuşmuyor", DPK4 "bazen Türkler bizi Suriyeli deyip dişliyor. Hem okulda hem mahalde... bazen de parka oynamaya gidiyoruz, orada Türkler bizim parktan gitmemizi istiyor", biçiminde dışlanmayı temel mutsuzluk kaynağı olarak ifade etmiştir. ÇÖYDÖ'den yüksek puan alan gruptaki çocuklardan YPK1 "yaşadığım yer okulumdan çok uzak ve mahallemde yeterince arkadaşım yok" biçiminde yaşadığ olarak belirtirken, YPK2 "genel olarak mutluyum”, YPK4 çünkü üzüleceğim şeylerle çok fazla karşılaşmıyorum", YPK3 "çok arkadaşım var" biçiminde mutsuz hissetmediklerini ifade etmiştir.

\section{Sonuç ve Tartışma}

Ankara ili Altındağ ilçesinde yaşayan ve zorunlu göçe maruz kalan çocukların psikolojik iyilik hallerinin ortaya çıkarılmasının amaçlandığı bu araştırmanın nicel bulgularına göre; çocukların ÇÖYDÖ genel yaşam doyumu puanlarının aritmetik ortalamalarının iyi seviyede olduğu anlaşılmaktadır. Araştırma kapsamında çocukların ÇÖYDÖ puanlarının cinsiyet, yaş ve sınıf düzeyi değişkenleri açısından farklılık gösterip göstermediği incelenmiş ve cinsiyet, yaş ve sınıf düzeyi değişkenleri açısıdan ÇÖYDÖ puanlarının istatistiksel olarak anlamlı bir farklılık göstermediği sonucuna ulaşılmıştır.

İlgili araştırmalar incelendiğinde; cinsiyet değişkeni açısından farklı sonuçlar olduğu görülmüş̧ür. Haring, Stock ve Okun (1984) tarafindan yaşam doyumu ve iyilik hali açısından erkeklerin kadınlardan daha avantajlı olduğu sonucuna ulaş1ırken, Lee, Seccombe ve Shelan (1991) kadınların erkeklerden öznel iyilik hali ve yaşam doyumu açısından daha avantajlı olduğu sonucuna ulaşmışlardır. Ryff, Magee, Kling ve Wing (1999) tarafından ise kadın ve erkekler arasında yaşam doyumu ve öznel iyilik hali açısından anlamlı farklılıklar olmadığ 1 ifade edilmiştir. Araştırma sonuçlarına göre, kızlar ve erkeklerin yaşam doyumu puanları arasında anlamlı bir farklılık olmaması, Çivitçi (2009), Elmas (2013) Gilman ve Huebner (2006), Gün ve Bayraktar (2008) tarafından yapılan araştırmaların sonuçlarıyla benzerlik göstermektedir. Fakat Huebner, Valois, Paxton ve Drane (2005), Nickerson ve Nagle (2004) ve Öztan'ın (2013) araştırma sonuçlarıyla çelişmektedir.

Yaş değişkeninin yaşam doyumu üzerindeki etkisini inceleyen araştırmalar ele alındığında; farklı sonuçların bulunduğu görülmektedir. Goldbeck, Schmitz, Besier, Herschbach ve Henrich 
(2007) tarafindan yapılan çalışmada, mutluluk düzeyinin yaşla birlikte azaldığı sonucuna ulaşılmakla birlikte, Herzog ve Rodgers'in (1981) çalışmasında yaşam doyumunun yaşla birlikte azalmadığı, Horley ve Lavery'nin (1995) çalışmasında ise yaşam doyumunun yaşla birlikte arttı̆̆ 1 sonucuna ulaşılmıştır.

Sınıf düzeyinin yaşam doyumu üzerinde etkisi hakkında farklı araştırma sonuçları bulunmaktadır. Araştırma sonuçlarıyla benzer olarak, Gilman ve Huebner (2006), Huebner (1994) ve Öztan'ın (2014) çalışmalarında, yaşam doyumu puanlarının sınıf düzeyi açısından istatistiki olarak anlamlı derecede farklılaşmadığı sonucuna ulaşılırken, Çivitçi’nin (2009) çalışmasında ise, 6. ve 7. Sınıftaki çocukların 8. Sınıftaki çocuklara göre yaşam doyumlarının daha fazla olduğu sonucuna ulaşılmıştır.

Görüşme yapılan tüm çocukların maddi-fiziksel iyilik hali açısından benzer özellikler gösterdikleri ve karşılamakta zorlandıkları top, bilgisayar ve elbise gibi çeşitli ihtiyaçlarının olduğu, maddi gelir seviyelerinin benzer olduğu sonucuna ulaşılmıştır. Akın ve Akın (2015) tarafından, kazanç ile iyi olma arasındaki ilişkinin belirgin olmadığı ifade edilmiştir. Diğer yandan, Çivitçi (2009) tarafından, cep telefonuna sahip olan çocukların cep telefonu olmayanlara göre yaşam doyumları ve öznel iyilik hallerinin daha yüksek olduğu belirtilmiştir.

Çocukların kalıcı etkileri bulunan tıbbi işleme maruz kalma ve korku kaynakları incelendiğinde, ÇÖYDÖ'den düşük puan alan gruptaki çocukların, hem kalıcı etkileri bulunan tıbbi işleme maruz kalma açısından hem de korku kaynakları açısından ÇÖYDÖ'den yüksek puan alan gruptaki çocuklardan görece daha olumsuz yaşam deneyimlerine sahip olduğu sonucuna ulaşılmıştır. ÇÖYDÖ'den düşük puan alan gruptaki çocuklar, yaşadıkları mahalleyi 1ssız ve çok köpek bulunması nedeniyle güvensiz bir yer olarak değerlendirmiş ve benzer bir biçimde çocukların korku duygularının kaynağının da yaşadıkları mahallenin içinde bulunduğu şartlar çerçevesinde gelişebileceği sonucuna ulaşılmıştır. Çocukların yaşadıkları yerlerin coğrafi özellikleri de çocuğun gelişimi ve sağlıklı uyumu üzerinde etkilidir (Barker \& Weller, 2003; Matthews, Limb \& Taylor, 2000). Araştırma sonuçlarına göre, ÇÖYDÖ’den düşük puan alan gruptaki çocukların ÇÖYDÖ'den yüksek puan alan gruptaki çocuklara göre daha fazla korku kaynaklarına sahip olması ve yaşam doyumu farklılıklarının çocukların içinde yaşadıkları mahallenin coğrafi koşullarıyla ilgili olması Homel ve Burns (1989) tarafindan gerçekleştirilen araştırmanın sonuçlarıyla örtüşmektedir.

Çocukların eğitimsel iyilik halleri, okula devam-devamsızlık durumu, ders kitabı haricinde kitap bulunup bulunmama durumu açısından incelenmiştir. Görüşme yapılan tüm çocukların eğitimsel iyilik hali açısından benzer özellikler gösterdikleri sonucuna ulaşılmıştır. Çocuklar 2017-2018 eğitim-öğretim yılının birinci döneminde çeşitli sebeplerle bir ile 10 gün aralığında okula devam etmemiştir. Devamsızlık nedenleri arasında hastalıklar, yetişkin rolüne bürünüp ebeveyn ile evin bir ihtiyacını giderme, engelli olan amcalarının bakımını geçici olarak üstlenme, misafir geleceği için anneye yardım etme veya okula gitmekteki isteksizlik ve keyfi olarak devamsızlık yapma bulunmaktadır. Polat ve Hoşgörür (2015) ve Şanlı, Altun ve Tan (2015) tarafindan gerçekleştirilen çalışmalarda devamsızlık nedenleri genel olarak ailesel nedenler, hastalık ve arkadaş çevresi nedeni olduğu sonucuna ulaşılmıştır. Araştırma sonuçlarının devamsızlık nedenleri açısından, Polat ve Hoşgörür (2015) ile Şanlı ve diğerleri (2015) tarafindan gerçekleştirilen çalışmalarla kısmen benzer olduğu sonucuna ulaşılmıştır.

Çocukların kişilerarası ilişkiler alt boyutunda aile üyeleri ile ilişkilerinin benzer olduğu fakat arkadaşları ile ilişkilerinin farklılık gösterdiği sonucuna ulaşılmıştır. Araştırmanın nitel boyutuna katılan tüm çocukların anne, baba ile vakit geçirme biçimlerinin akşam yemekleri, tv seyretme veya anneye yardım etme şeklinde olduğunu, kardeşleri ile vakit geçirme biçimlerinin ise akşam yemekleri, tv seyretme ve anneye yardım etmenin yanı sıra oyun oynama şeklinde 
olduğu sonucuna ulaşılmıştır. Aile üyeleri çocuğun sağlklı gelişimi ve topluma katılımı açısından çok önemlidir (Berk, 2013). Destekleyici aile ilişkileri çocuğun olumlu gelişimini ve hayata katılımını şekillendirmektedir (Hefferon \& Boniwel, 2014). Araştırma kapsamında çocuklar tarafından aile üyeleriyle geçirilen sürede, akşam yemekleri, dizi/tv seyretme, anneye yardım etme ve oyun oynama etkinliklerinin yapıldığı belirtilmiş fakat, sorunların paylaşılması ve problemin çözümü için ebeveynden veya yetişkinden yardım alma gibi yollara başvurulması konusunda herhangi bir bilgi verilmemiştir. Bu durum ebeveynlerinin çocuklarının duygusal süreçleri ile ilgilenme konusunu geçim kaygısı ve diğer zorluklar nedeniyle daha az önem verilmiş olabileceği veya toplulukçu kültürel yapıyla ilişkilendirilebilir (Buz, 2003; Kashima \& Hardie, 2000).

ÇÖYDÖ'den düşük puan alan gruptaki çocukların, arkadaş çevrelerine dair yaşadıkları problemlerin ÇÖYDÖ'den yüksek puan alan gruptaki çocuklara göre daha fazla olduğu ve çocukların bu durumdan çok rahatsız olduğu sonucuna ulaşılmıştır. İnsanların içerisinde yaşadığı kültürel bağlam psikolojik iyilik hali üzerinde etkilidir (Christopher, 1999). Farklı kültürler iyilik haline ilişkin farklı kavramsallaştırmalara sahiptir. Bireyselliğin öne çıkarıldığ 1 toplumlarda benlik yapısı bireysel hazlar ve istekler üzerine odaklanırken, ilişkiselliğin öne çıkarıldığ 1 toplumlarda kişilerarası ilişkilere verilen önem daha fazla olmakta ve yaşamdan elde edilen doyum üzerinde yakın çevre ile ilişkiler etkili olmaktadır. Toplulukçuğun öne çıkarıldığı toplumlarda ise birey eyleme geçerken ait olduğu grup ve toplumun hedeflerini ön planda tutarak doyum sağlar (Kashima \& Hardie, 2000). Araştırma çerçevesinde ÇÖYDÖ’den düşük puan alan gruptaki çocukların Türk akranları ile daha fazla problem yaşaması ve bu duruma iliş̧kin rahatsızlıklarını belirtmeleri, ilişskiselliğin ön planda olduğu bir bağlamda yetişmeleri ile ilgili olabileceği değerlendirilmektedir.

Görüşme yapılan tüm çocukların davranışlar ve riskler alt boyutunda farklı özellikler gösterdikleri sonucuna ulaşılmıştır. Çocukların akşam öğününde birşeyler yeme konusunda herhangi bir problem yaşamadığı fakat ÇÖYDÖ'den düşük puan alan gruptaki çocukların sabah ve öğle öğünlerinde bir şeyler yeme konusunda daha dezavantajlı olduğu sonucuna ulaşılmıştır. Kahvaltı başta olmak üzere öğünlerde bir şeyler yememek çocuk ve gençlerde okul başarısını olumsuz etkiler ve dengesiz ve yetersiz beslenme alışkanlığı kazanılmasına sebep olur (Goloğlu, 2009). ÇÖYDÖ'den düşük puan alan gruptaki çocukların sabah ve öğlen öğünlerinde düzenli olarak bir şeyler yemeden geçirmesinin psikolojik iyilik hallerini olumsuz etkileyebileceği değerlendirilmektedir.

Görüşme yapılan tüm çocukların Türk akranlarıyla tartışma ve kavga yaşama gibi sözel ve fiziksel şiddet olayları ile karşılaştıkları sonucuna ulaşılmıştır. Çocukların şiddet algısı göz önünde bulundurulduğunda, Türk akranlar ile hâlihazırda var olan gruplaşmaların, çocukların içinde bulunduğu gelişim dönemi çerçevesinde cinsiyet, tutulan takım ve ait olunan grup açısından beklenen bir durumdur (Berk, 2013). Fakat çatışma ve gruplaşmaların Türk-Suriyeli çatışması haline dönüşmesi istenmeyen bir durumdur. Bu gruplaşmaların temelinde geçirilen bir takım yaşantılar olmakla birlikte, ebeveynler, yakın çevre ve kitle iletişim araçlarının bazı önyargıları pekiştirmesi de etkilidir (Göker \& Keskin, 2015). Nitekim Suriye uyruklu yabancıların Türkiye'ye etkileri hakkında yerel halkın görüşlerinin alındığı birkaç çalışmada kaynakların kullanımının şehirdeki nüfus yoğunluğu nedeniyle kısıtlanması (Sönmez \& Adıgüzel, 2017) önyargıların artmasına (Aslan, 2017) sebep olmuştur ve mevcut araştırmada bu önyargıların çocuklara da yansımasının söz konusu olduğu düşünülmektedir.

Çocukların psikolojik iyilik hali alt boyutunda farklı özelliklere sahip olduğu ve bu farklılığın ÇÖYDÖ’den yüksek puan alan gruptaki çocukların lehine olduğu sonucuna ulaşılmıştır. Araştırma sonuçlarına göre, ÇÖYDÖ'den düşük puan alan gruptaki çocukların mutluluk düzeylerini ÇÖYDÖ'den yüksek puan alan gruptaki çocuklara göre daha düşük düzeyde ifade 
ettiği anlaşılmıştır. ÇÖYDÖ'den düşük puan alan gruptaki çocukların mutsuzluk kaynaklarının ise, Suriye'deki savaş ve göç, akranları ve yetişkinler tarafından dışlanmaya maruz kaldıklarını hissetme biçiminde olduğu ve bu durumun Kuru (2020) tarafından yapılan araştırma sonuçlarıyla benzerlik gösterdiği sonucuna ulaşılmıştır. Mutsuzluk oluşturan spesifik yaşantıların yanı sıra çocukların dışlanmaya maruz kaldığını hissetmesi, araştırmanın kişilerarası ilişkiler alt boyutu sonuçlarıyla örtüşmektedir. Doğu toplumlarında öne çıkan benlik yapıları çerçevesinde çocuğun kültürel olarak beklentiye girdiği ilişkiler imgesi ile mevcut ilişkiler arasındaki farklılıkların çocukların dışlandıklarını hissetmesine neden olduğu düşünülmektedir.

Çocukların psikolojik iyilik halini sürdürebilmek ve zorunlu göçün olumsuz etkilerinden en az etkilenmelerinin sağlanması için mevzuat düzenleyicilere, akademisyenlere ve öğretmenlere çeşitli görevler düşmektedir. Mevzuat düzenleyiciler çocukların psikolojik iyilik halinin sürdürülebilmesi için gerekli olan yasal düzenlemeleri çocukların durumlarını göz önünde bulundurarak ve çocukların katılım haklarını dikkate alarak gerçekleştirmelidir. Zorunlu göçün çocukların ruh sağlığını olumsuz etkilemesinin önüne geçilebilmesi için çocukla ilgili paydaşlar (devlet kurumları, akademisyenler, sivil toplum örgütleri) ile iş birliği artırılmalı ve yerinden edilen çocukların ihtiyaç duydukları anda müracaat edebilecekleri ruh sağlığı uzmanları okullar başta olmak üzere çeşitli kurumlarda görevlendirilmelidir. Ayrıca zorunlu göçe maruz kalmanın çocuklar üzerindeki olası etkileri konusunda yapılan araştırmalar artırılmalı, araştırmalarda çocuğun araştırma sürecine katılımını sağlayacak, çocukların kendisini ifade etmesini kolaylaştıran çocuk dostu araştırma yöntemleri kullanılmalıdır. Diğer taraftan çocukların hem okulda hem de sosyal hayatta Türk-Suriyeli çatışmasına girmemesi ve sağlıklı sosyal ilişkiler geliştirebilmesi için birlikte yapılabilecekleri bazı sosyal etkinlikler özendirilmelidir. $\mathrm{Bu}$ etkinlikler eşit sayıda Türk ve Suriyeli çocukların bulunduğu takımlarla futbol, basketbol, voleybol turnuvaları gerçekleştirilebilir, ya da birlikte sinema, piknik etkinlikleri biçiminde yapılabilir. Ayrıca çocuklarda erken çocukluk döneminden itibaren farklılıklara saygı anlayışının gelişmesi için çeşitli proje ve planlar uygulanarak çeşitli önlemler alınmalıdır.

\section{Kaynaklar}

Abdul-Rida, C., \& Nauck, B. (2013). Migration and child well-being. In A. Ben-Arieh, F. Casas, I. Frones \& J. E. Korbin (Eds.), Handbook of child well being (pp. 3101-3142). New York: Springer.

Adamson, P. (2013). Child well-being in rich countries: A comparative overview. UNICEF Innocenti Report Cart 11. UNICEF Office of Research, Florence.

Aker, T. (2006). Zorunlu göç yaşayan ailelerin ikinci kuşak üyelerinin sağlık durumu (Yayınlanmamış yüksek lisans tezi). Kocaeli Üniversitesi Sağlık Bilimleri Enstitüsü, Kocaeli.

Akın, A., \& Akın, Ü. (2015). Psikolojide güncel kavramlar: Pozitif psikoloji. Ankara: Nobel Akademik Yayıncılık.

Aslan, C. (2017). Türkiye'nin yeni “ötekileri”: Suriyeliler. Route Educational and Social Science Journal, 4(8), 335-341.

Barker, J., \& Weller, S. (2003).'Never work with children?': The geography of methodological issues in research with children. Qualitative Research, 3(2), 207-227.

Berk, L. (2013). Bebekler ve çocuklar (Çev. Ed. N. I. Erdoğan). Ankara: Nobel Akademik Yayıncilik.

Buz, S. (2003). Aile politikalarına mülteciler boyutunda bir bakış. Aile ve Toplum, 5(2), 1-7. 
Büyüköztürk, Ş. (2008). Sosyal bilimler için veri analizi el kitabı (9. baskı). Ankara: Pegem Akademik Yayıncilık.

Casas, F. (1998). Children's rights and children's quality of life: Conceptual and practical issues. Social Indicators Research, 42, 283-298.

Castles, S., \& Miller J., M. (2008). Göçler çağı. modern dünyada uluslararası göç hareketleri. İstanbul: İstanbul Bilgi Üniversitesi Yayınları.

Christopher, J., C. (1999). Situating psychological well-being: Exploring the cultural roots of its theory and research. Journal Of Counselling And Development, 77, 141-152.

Creswell, J. (2016). Araştırma deseni. Nicel, nitel ve karma yöntem yaklaşımları (Çev Ed: S. B. Demir). Ankara: Eğiten Kitap.

Çivitci, A. (2007). Çokboyutlu öğrenci yaşam doyumu ölçeğinin Türkçe'ye uyarlanması: Geçerlik ve güvenirlik çalışmaları. Eurasian Journal of Educational Research, 26, 5160.

Çivitçi, A. (2009). İlköğretim öğrencilerinde yaşam doyumu: Bazı kişisel ve ailesel özelliklerin rolü. Uludağ Üniversitesi Ĕ̈itim Fakültesi Dergisi, 22(1), 29-52.

Ekblad, S. (1993). Psychosocial adaptation of children while housed in a Swedish refugee camp: aftermath of the collapse of Yugoslavia. Stress Med, 9, 59-66.

Elmas, İ. H. (2013). Ortaögrretim ögrrencilerinin hayat tatmin düzeyleri (Yayınlanmamış yüksek lisans tezi). Hasan Kalyoncu Üniversitesi Sosyal Bilimler Enstitüsü, Gaziantep.

Gez, A. (2018). Suriyeli çocuk ve ergenlerde algılanan sosyal destek ve psikolojik sağlamlık arasındaki ilişsi (Yayınlanmamış yüksek lisans tezi). Çă̆ Üniversitesi Sosyal Bilimler Enstitüsü, Adana.

Gilman, R., \& Huebner, E. S. (2006). Characteristics of adolescents who report very high life satisfaction. Journal of Youth and Adolescence, 35, 293-301.

Glesne, C. (2013). Nitel araştırmaya giriş. Ankara: Anı Yayıncılık.

Goldbeck, L., Schmitz, T. G., Besier, T., Herschbach, P., \& Henrich, G. (2007). Life satisfaction decreases during adolescence. Quality of Life Research, 16(6), 969-979.

Goloğlu, S. (2009). Fen eğitiminde sosyo-bilimsel aktivitelerle karar verme becerilerinin gelişstirilmesi: dengeli beslenme (Yayınlanmamış yüksek lisans tezi). Marmara Üniversitesi Eğitim Bilimleri Enstitüsü, İstanbul.

Göker, G., \& Keskin, S. (2015). Haber medyası ve mülteciler: Suriyeli mültecilerin türk yazılı basınındaki temsili. Iletişim Kuram ve Araştırma Dergisi, 41, 229-258.

Gün, Z., \& Bayraktar, F. (2008). Türkiye'de iç göçün ergenlerin uyumundaki rolü. Türk Psikiyatri Dergisi, 19, 167-176.

Haring, M., J., Stock, W., A., \& Okun, M., A. (1984). A research snynhesis os gender and social class as correlates of subjective well-being. Human Relations, 37, 645-657.

Hefferon, K., \& Boniwell I. (2014). Pozitif psikoloji: kuram, uygulama ve araştırmalar. (Çev. Ed., Tayfun Doğan). Ankara: Nobel Akademik Yayıncılık.

Herzog, A. R., \& Rodgers, W. L. (1981) The scructure of subjective well-being in different age groups. Journal of Gerontology, 36(4), 472-479.

Hjern, A., Angel, B., \& Hojer, B., (1991). Persecution and behavior: A report of refugee children from Chile. Child Abuse Neglect, 15, 239-248. 
Homel, R., \& Burns, A. (1989). Environmental quality and the wellbeing of children. Social Indicators Research, 21(2), 133-158.

Horley, J., \& Lavery, J. J. (1995) Subjective well being and age. Social Indicator Research, 34 , 257-282.

Huebner, E. S. (1991). Initial development of the Students' Life Satisfaction Scale. School Psychology International, 12, 231-240.

Huebner, E. S., Valois, R. F., Paxton, R. J., \& Drane, J. W. (2005). Middle school students' perceptions of quality of life. Journal of Happiness Studies, 6, 15-24.

Johnson, B., \& Christiansen, L. (2014). Eğitim araştırmaları. nicel, nitel ve karma yaklaşımlar (Çev. Ed. Selçuk Beşir Demir). Ankara: Eğiten Yayınevi.

Karasar, N. (2013). Bilimsel araştırma yöntemi (26. baskı). Ankara: Nobel Akademik Yayınc1lik.

Kashima, E., \& Hardie, A. E. (2000). The development and validation of the relational, individual and collective self aspects RIC scale. Asian Journal of Social Psychology, 3, 19-48.

Kaya, A., \& Siyez. D. M. (2008). Farklı sosyometrik statülerdeki ilköğretim öğrencilerinin yaşam doyumu düzeylerinin incelenmesi. Eurasian Journal of Educational Research, $32,69-82$.

Kocijan-Hercigonja, D., Rijavec, M., Marusic, A., \& Hercigonja, V. (1998). Coping strategies of refugee, displaced, and non-displaced children in a war area. Nord J Psychiat, 52, $45-50$.

Kuru, N. (2020). Tamamlayıcı erken müdahale programının mülteci çocukların benlik saygısına, sosyal becerilerine ve psikolojik sağlamlı̆̆ına etkisi (Yayınlanmamıș doktora tezi). Hacettepe Üniversitesi Eğitim Bilimleri Enstitüsü, Ankara.

Lee, G., R., Seccombe, K., \& Shelan, C., L. (1991). Marital status and personal happines: an analysis of trend data. Journal Of Marriage And The Family, 53, 504-531.

Matthews, H., Limb, M., \& Taylor, M. (2000). The street as thirdspace. children's geographies: Playing, living, learning. London: Routledge.

Miles, M. B., \& Huberman, A. M. (1994). Qualitative data analysis: An expanded sourcebook (2nd ed.). London: Sage.

Nickerson, A. B., \& Nagle, R. J. (2004). The influence of parent and peer attachments on life satisfaction in middle childhood and early adolescence. Social Indicators Research, 66, 35-60.

Özer, S., Şirin, S., \& Oppedal, B. (2013). Bahcesehir study of Syrian refugee children in Turkey. 15.12.2017

tarihinde https://www.fhi.no/globalassets/dokumenterfiler/moba/pdf/bahcesehir-study-report adresinden erişildi.

Öztan, S. (2013). Ortaokul 6.7.8. sını öğrencilerinin okul tükenmişliklerinin yaşam doyumları ve benlik kurgusu algıları açısından incelenmesi (Yayınlanmamış yüksek lisans tezi). Arel Üniversitesi Sosyal Bilimler Enstitüsü, İstanbul.

Polat, M., \& Hoşgörür, V. (2015). Ortaokul öğrencilerinin okula devamsızlık nedenleri. $M K S U$ Ĕ̈itim Fakültesi Dergisi, 2(1), 25-42. 
Rothe, E. M., Lewis, J., Castillo-Matos., H., Martinez, O., Busquets, R., \& Martinez, I. (2002). Posttraumatic stress disorder among Cuban children and adolescents after release from a refugee camp. Psychiatr Serv, 53, 970-976.

Ryff, C. D., Magee, W. J., Kling, K. C., \& Wing, E. H. (1999). Forging macro-micro linkages in the study of psychological well-being. In C. D. Ryff \& V. W. Marshall (Eds.). The self and society in aging processes (pp. 247-278). New York: Springer.

Sağlam, S. (2006). Türkiye'de iç göç olgusu ve kentleşme. Hacettepe Üniversitesi Türkiyat Araştırmaları Enstitüsü Dergisi, 5, 33-44.

Servan-Schreiber D., Le Lin B., \& Birmaher, B. (1998). Prevalence of posttraumatic stress disorder and major depressive disorder in tibetan refugee children. $J$ Am Acad Child Adolesc Psychiatry, 37(8), 874-9.

Sourander A. (1998). Behavior problems and traumatic events of unaccompanied refugee minors. Child Abuse Neglect, 22, 719-27.

Sönmez, M., \& Adıgüzel, F. (2017). Türkiye'de suriyeli sığınmacı algısı: Gaziantep şehri örneği. Gaziantep University Journal of Social Sciences, 16 (3), 797-807.

Şanlı, Ö., Altun, M., \& Tan, Ç. (2015). Okula devamsızlık yapan öğrencilerin devamsızlık sebeplerinin öğrenci görüşlerine göre değerlendirilmesi. Elektronik Sosyal Bilimler Dergisi, 14(55), 161-177.

Şirin, S., \& Rogers-Şirin, L. (2015). The educational and mental health needs of syrian refugee children. Washington DC: Migration Policy Institute.

Uğurlu, N. (2015). Suriyeli göçmen çocuklarda sanat terapisinin travma, depresyon ve anksiyete semptomlarina etkisi (Yayınlanmamış Yüksek Lisans Tezi). Bahçeşehir Üniversitesi Sosyal Bilimler Enstitüsü, İstanbul.

Yıldırım, A., \& Şimşek, H. (2016). Sosyal bilimlerde nitel araştırma yöntemleri. Ankara: Seçkin Yayınevi.

\section{EXTENDED ABSTRACT}

\section{Introduction}

The life events that children may be exposed to after the forced migration and their effects may endanger the psychological well-being of children. While the persistence and sustainability of psychological well-being affects children's development positively, displacement and worsening of living conditions affect children negatively. Children who maintain psychological well-being by taking various measures can adapt to new lands more easily and develop their potential at the highest level in accordance with their development levels. Children with subjective well-being and happiness are at less developmental risk (Abdul-Rıda \& Nauck, 2013). Various researches have shown that some macro and micro measures taken to maintain psychological well-being contribute to a happier and more successful life (Adamson, 2013; Casas, 1998). Therefore, in this study, it is aimed to find out the factors that may impair the psychological well-being of children who are exposed to forced migration.

\section{Method}

In the current research, exploratory sequential mixed method was used. In the analysis process, qualitative and quantitative data are collected in mixed method researches and findings are integrated. The exploratory sequential mixed method is a study method in which the researcher 
conducts a qualitative phase following a quantitative phase. In this approach, the first stage collects quantitative data and analyzes its findings. In the second stage, qualitative research is carried out based on quantitative findings. (Creswell, 2016; Creswell \& Clark, 2015).

In the quantitative stage of the study, the personal information form prepared by the researcher and the Multidimensional Student Satisfaction Scale MSSL-TR adapted to Turkish by Çivitçi (2007) were applied to 96 students. The obtained data were analyzed the minimum and high score limits of the scores obtained from the MSSL-TR were determined. In the qualitative stage of the study, eight children with four low (two girls, two boys) and four high (two girls, two boys) scores were interviewed within the framework of semi-structured interview form. In the quantitative dimension of the study, it was concluded that the internal consistency value of children's general life satisfaction scores was ,834. It was concluded that the reliability of the qualitative dimension of the research was ,94 within the framework of the formula Reliability=Agreement/Agreement+Disagreement (Miles \& Huberman, 1994).

\section{Result}

According to the results of the research, the scores obtained from the MSSL-TR did not show a statistically significant difference in terms of gender, age and education class variables, and all children who were in the lower and higher score groups than the MSSL-TR showed similar characteristics in terms of physical well-being and has different needs (ball, computer, dress etc.) and financial income levels which are low. In addition, children who scored lower than the MSSL-TR were found to be unsafe due to the fact that their neighborhood was deserted and there were many dogs and more disadvantaged both exposure to medical procedures of lasting effects and fear sources.

It was found that all children in the low and high score limits of the MSSL-TR showed similar characteristics in terms of educational well-being and did not attend school for one to 10 days for various reasons during an academic year. The reasons for absenteeism were stated by children as follows; illnesses, taking on the role of adults to meet the need of a parent and home, taking care of their disabled uncles temporarily, helping the mother for the future of guests or reluctance to go to school.

Intercalarily it was found that all children in the low and high score groups of the MSSL-TR did not have any problem about eating something in the evening meal, but children who were within the low score groups of the MSSL-TR were more disadvantaged in the morning and lunch meals and all children within the low and high score groups of the MSSL-TR had similar perception, sources and type of violence and that they experienced physical and verbal violence in the form of discussions and fighting with Turkish students. It was concluded that the children in the group with a low score in MSSL-TR had more problems with their friends, and the children were very uncomfortable with this situation. Finally, it was concluded that children who scored higher than the MSSL-TR were happier than children who scored lower than the other.

\section{Discussion}

The results of this study were obtained from the children of Syrian nationality who were studying in 5th, 6th, 7th and 8th grades in the Altındag district of Ankara, who volunteered to participate in the study and that both themselves and their parents gave their consent to participate in the study. In order to maintain the psychological well-being of children and to minimize the negative effects of forced migration, legislators, academicians and teachers have various duties. Legislators should make the necessary arrangements in order to maintain the 
psychological well-being of children, taking into account the situation of children and taking into account the children's right to participate. In order to prevent forced migration from adversely affecting children's mental health, cooperation with child-related stakeholders (government agencies, academicians, non-governmental organizations) should be increased. In addition, research on the possible effects of forced migration on children should be increased, and child-friendly research methods should be used in the research to ensure the participation of the child in the research process.

\section{Etik Kurul İzin:}

Yapılan bu çalışmada "Yükseköğretim Kurumları Bilimsel Araştırma ve Yayın Etiği Yönergesi” kapsamında uyulması belirtilen tüm kurallara uyulmuştur. Araştırma Göç Uzmanlığı tezinden üretilmiş olup veriler 2020 yılı öncesinde toplanmıştır. Araştırmanın yürütülebilmesi için Göç İdaresi Genel Müdürlügü ve Ankara İl Milli Eğitim Müdürlügünden yasal izinler alınmıştır. 